\title{
Financial Feasibility Study of Hydro Power Plant on A River in West Sumatra
}

\author{
Sidhi Razinda Kautsar and Sylviana Maya Damayanti
}

\begin{abstract}
As a part of nation worldwide, Indonesia set the target for the renewable energy source. The renewable energy should be $23 \%$ of the energy mix generation that mentioned in the RUPTL 2019 -2028. PT. XYZ as the company which have the responsibility regarding the electricity in Indonesia should work hard to find and invest in renewable energy source. In West Sumatra, there is one river that can be potential to create the hydro power plant that expected to generate as much as 296.104.624 $\mathrm{kWh}$. The construction of the hydro power plant itself will be started from the scratch that obviously will cost much money. The company should consider if it is wise to invest in constructing the hydro power plant or not. This research aims to analyze the financial feasibility study of the hydro power plant in West Sumatra, the financial performancef of the project, and find which variable that affect the project greatly. This research performs general environment analysis using PESTEL analysis to identify whether the environment support the project execution or not. The financial feasibility analysis performs using the discounted cashflow method and evaluated using Net Present Value (NPV), Internal Rate of Return (IRR), and Payback Period (PP). To identify which variable that affected the financial feasibility of the project, the author use sensitivity analysis and scenario analysis. Furthermore, Monte Carlo simulation also performed in this research to give an information regarding the probability impact of the uncertainty from the selected variable. The calculation result shown that the project is financially feasible with NPV of Rp. 1.832.776.500.481, IRR of $15,77 \%$ which is higher than the weighted average cost of capital (WACC), and the payback period for 9,15 years. The financial performance also shown a favourable result with the project's profitability index of 5,41 . Long-term debt interest rate, capacity factor, agreement price, CAPEX need, and inflation rate are the highest five variable that affect the feasibility of the project. According the Monte Carlo simulation result using 1000 iterations, the project has probability of $6,34 \%$ in making the project not feasible.
\end{abstract}

Index Terms - discounted cashflow, PESTEL analysis, renewable energy, Monte Carlo Simulation.

\section{INTRODUCTION}

The sustainable development goals are an agenda that agreed by the nations to be achieved in 2030. The sustainable development goals number 7 is focused on providing sustainable energy for all. There are three subgoals for goal number 7 that they should ensure by 2030, there are universal access to affordable, reliable, and modern energy services, the share of renewable energy in the global mix should be increased substantially, and the global rate of

Published on December 31, 2020.

Sidhi Razinda Kautsar, Institut Teknologi Bandung, Indonesia.

(corresponding e-mail: sidhi.razinda ${ }^{@}$ sbm-itb.ac.id)

Sylviana Maya Damayanti, Institut Teknologi Bandung, Indonesia. improvement in energy efficiency should be doubled [9]. As a part of nations worldwide, Indonesia also support this agenda, this condition can be seen regarding the national mid-long terms plan 2018-2024. In the National Mid-LongTerm Development Plan (RPJMN) 2019-2024, Indonesia should have $20 \%$ portion of renewable energy with 37,3 GW capacity of renewable energy power plant [3]. The target translated by the PT. XYZ in Electricity supply plan 2019-2028 (RUPTL) with the energy generation mix that comes from renewable energy source should reach $23 \%$ in 2025 , while according to the last Indonesian energy outlook, the use of renewable energy for electricity generation is $14 \%$ from total capacity of electricity generation.

As the gap of the target with the actual condition is quite far, PT. XYZ should work hard to fill in the gap. There are so much potential resources that can be used to produce energy for electricity generation, but there still need some consideration before doing an investment to build the power plant. One of the potential resources that will be constructed to become a power plant is the river in the West Sumatra. The power plant that will be constructed in one of the rivers in the west Sumatra will need a reservoir to be built first. The power plant is expected to have $60 \mathrm{MW}$ potential power that will generate energy as much as $296.104 .624 \mathrm{kWh}$. It will be helpful for PT. XYZ to consider in investing their money to build the power plant in that river. But, as the power plant will be created from the scratch, the company still consider about the capital expenditure that they need, the operating expenses that will occur, how much revenue that the company will generate, and the most important thing is whether the investment will be feasible or not based on the financial performances of the project.

This research aims to analyze the financial feasibility study of the hydro power plant in West Sumatra, the financial performance of the project, and find which variable that affect the project greatly.

\section{BUSINESS ANALYSIS SITUATION}

In order to deepen the analysis, business situation analysis performed using external and internal analysis. The external analysis will use the PESTEL analysis to identify the macroenvironment that might affect the company's strategy which can help the company to be able to face the possibility of future changes in dynamic environment [6] [8]. On the other hands, due to the data restriction, the internal analysis will perform by analyzing the project overview.

Overall, from the PESTEL analysis that have been performed before, most of the macro-environment factor support the execution of the project. The policy supports the execution of project with the target that need to be achieved 
by the country, while the social factor supports with its population growth which can increase the electricity demand, and the project execution also become a reason to decrease the unemployment rate because the new power plant will give an opportunity to the unemployment. There is also an opportunity opens for the company to create partnership with private sector, as it mentioned in the economical factor that the private participation in investing their money in the energy sector are higher than the other sector which shows there is possibility that the private company will invest their money again for the energy sector in the future. Those opportunity also supported by the regulation that give an easier access for the private to do an investment in renewable energy sector. Even though most of the macro-environmental factor support the execution of the project, there is also an action that need to be done by the company to prevent an undesirable outcome that might happen cause by the future change in the macroenvironmental factor. As the project is a long-term project with 25 years period of the project and 7 years construction process, there is an uncertainty that might be happened in the middle of the project execution.

The project overview shown that the hydro power plant will have potential $60 \mathrm{MW}$ power using the river debit which can produce energy as much as 296.104.624 kWh with the capacity factor as much as $55 \%$. The construction process for the project will takes time for 84 months or 7 years. As the construction process takes much time, the company should be aware with the uncertainty that might be happened in the construction process. The uncertainty that might be happened commonly related with the cost overrun and schedule overrun [1].

\section{Methodology}

The first step in this research will be the business situation analysis. The business situation analysis will be conducted by doing the analysis of the condition related with the development project of the hydro power plant in West Sumatra. The analysis will divide into two parts which is external and internal analysis. The external analysis will be focused on the general environmental approach which divided into political, economic, social, environmental, and technological aspects. On the other side, the internal analysis will be focused on the project overview related with the specification of the project.

The next step will be the financial calculation of the feasibility studies. The calculation will be initiated by calculating the projection of revenue and cost, then followed by the cash flow projection using the discounted cash flow analysis. In order to decide whether the project is financially feasible or not, this research will use three methods of analysis which is Net Present Value (NPV), Internal Rate of Returns (IRR), and Payback Period (PP) as the parameters. If the result shown its not feasible, then there will be another alternative to be proposed so that the financial projection will become feasible.

Furthermore, this research will conduct the sensitivity, scenario analysis, and Monte Carlo simulation to determine the influence of some variables toward the financial projections. The output from sensitivity, scenario analysis, and Monte Carlo simulation will become the consideration and recommendation for related stakeholders to take attention to maintain the feasibility of this project.

\section{FINDINGS AND ARGUMENTS}

\section{A. Defining Assumption}

Since the data provided was limited, the research proposes some assumption using several sources such as secondary data and historical data from similar line of business companies i.e., PT Indonesia Power [5].

\section{B. Interest Rate and Loan Schedule}

The construction of hydro power plant in West Sumatra finance its project by using $70 \%$ loan from the total funds which derives from bank with maturity time of 15 years and $30 \%$ comes from the equity. The financing proportion using $70 \%$ of loan and $30 \%$ of equity also mentioned in the clean energy handbook by Financial Service Authority (OJK) as the reference for the upcoming renewable energy project [4] In addition, the composition for the financing itself are commonly used as the financing mix in power plant project. The interest rates used is the latest Indonesia's lending interest rates that derives from the World Bank's data which is $10,36 \%$ [10].

\section{Weighted-Average Cost of Capital (WACC)}

As PT. XYZ is not a listed company, the calculation of the beta value will use the beta of power industry in US as a proxy for the PT. XYZ beta. The unlevered beta for power industry in US is 0,37 . Then, the beta value of PT. XYZ for this project is 3,12 considering the debt equity ratio of 2,33 and the corporate $\operatorname{tax} 25 \%$ in Indonesia. The used of the average beta of power industry as a proxy is commonly used in the previous project related with the power plant project.

In calculating the WACC, the cost of debt and cost of equity should be determined first. From the calculation using capital asset pricing model it was found that the cost of equity is $12,8 \%$, while the cost of debt calculation resulted $7,77 \%$. By multiplied the weight with each cost, it was found that the WACC is $9,28 \%$.

\section{Income Statement Assumption}

The revenue projection for the hydro power plant project will use following assumption:

- The revenue generates from the electricity production from the hydro power plant that operates for 24 hours every day in a year with capacity factor $55 \%$.

- The production capacity assumed to be operated in maximum capacity over the year.

- The electricity will be transmitted to the interconnection in the Pangkalan Kota Baru, so that the energy produce will be bought fully by the company.

- The pricing policy will refer to the power generation price sold which is $85 \%$ of the region power generation cost.

- The price will growth as the inflation rate.

While for the operation expenditures will be divided into four components which are fuel and lubricants expenses, maintenance expenses, general administrative and management expenses, and direct labor expenses. fuel and 
lubricants expenses, maintenance expenses, and general administrative and management expenses will refer to the benchmark historical data from PT. Kencana Energi Lestari, while for the direct labor expenses will use 30 persons as direct labor with the wage as much as the minimum region wage of West Sumatra.

\section{E. Financial Feasibility Analysis}

Using previous assumption, the Free Cashflow to the Firm (FCFF) can be calculated and the feasibility of the project can be evaluated. The parameter that used to define the project is feasible are net present value (NPV), internal rate of return (IRR) and the payback period which should be paid back before the project period ends. The calculation for net present value (NPV) and internal rate of return (IRR) will use the weighted average cost of capital (WACC) as the discounted rate with amount $9,28 \%$. The calculation resulted the positive value of net present value (NPV) of Rp. $1,832,776,500,481$ and the internal rate of return (IRR) of $15,77 \%$ which is greater than the weighted average cost of capital (WACC), and the payback period for 9,15 years. In addition, the project's profitability index is 5,41 which means the project is favorable and profitable enough. Due to the result passed all the parameter criteria, it can be concluded that the project is financially feasible.

\begin{tabular}{cc} 
TABLE I: FINANCIAL FEASIBILITY PARAMETER \\
\hline DCF Parameter & Value \\
\hline Payback Period & 9,15 \\
Discounted Payback Period & 11,14 \\
Net Present Value & 1.832 .776 .500 .481 \\
Profitability Index & 5,41 \\
IRR & $15,77 \%$ \\
\hline
\end{tabular}

\section{F. Sensitivity Analysis}

Sensitivity analysis is an approach to know how impactful value changes in a variable to the value of objective model. It was usually done by changing the number of some variables and finding which variables that affect the target variable the most [7] [2]. The sensitivity analysis results shown in the figure below.

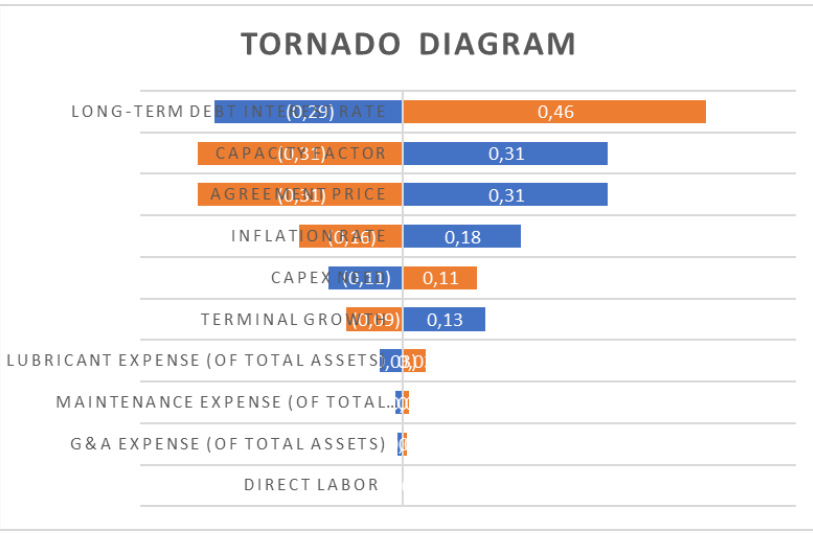

Fig. 1. Tornado Diagram.

\section{G. Scenario Analysis}

Scenario analysis created by the author in three kind of scenarios which are base-case scenario, worst-case scenario, and best-case scenario. The base-case scenario reflected the typical scenario or most likely scenario, while the worstcase scenario reflected the most extreme condition that can happen when things do not go as planned, and best-case scenario reflected the most preferred possible result.

TABLE II: WORST CASE SCENARIO ANALYSIS

\begin{tabular}{|c|c|}
\hline & Worst Case \\
\hline Capex need (In Million IDR) & 1.360 .984 \\
\hline Inflation Rate & $2,48 \%$ \\
\hline Long-Term Debt Interest Rate & $14,50 \%$ \\
\hline Agreement Price & $45 \%$ \\
\hline Capacity Factor & $35 \%$ \\
\hline NPV (In Million IDR) & $(265.749)$ \\
\hline \multicolumn{2}{|c|}{ TABLE III: BASED CASE SCENARIO ANALYSIS } \\
\hline & Base Case \\
\hline Capex need (In Million IDR) & 756.102 \\
\hline Inflation Rate & $3,34 \%$ \\
\hline Long-Term Debt Interest Rate & $10,36 \%$ \\
\hline Agreement Price & $85 \%$ \\
\hline Capacity Factor & $55 \%$ \\
\hline NPV (In Million IDR) & 1.832 .776 \\
\hline \multicolumn{2}{|c|}{ TABLE IV: BEST CASE SCENARIO } \\
\hline & Best Case \\
\hline Capex need (In Million IDR) & 680.492 \\
\hline Inflation Rate & $4,37 \%$ \\
\hline Long-Term Debt Interest Rate & $10,37 \%$ \\
\hline Agreement Price & $100 \%$ \\
\hline Capacity Factor & $60 \%$ \\
\hline NPV (In Million IDR) & 3.059.503 \\
\hline
\end{tabular}

\section{H. Monte Carlo Simulation}

Monte Carlo analysis is necessary to be done in order to know the impact risk of uncertainty from the model that built. The Monte Carlo analysis done by doing a simulation for the uncertain variable. In this research the uncertain variable that will be tested by Monte Carlo simulation analysis is the same variable from scenario analysis. The range for the probability for each variable will be the range between the worst scenario to the best scenario. The simulation itself will be done using 1000 iteration. The result for the Monte Carlo simulation analysis can be seen in the following table.

TABLE V: Monte CARLo Simulation RESUlt

\begin{tabular}{cc}
\hline \multicolumn{2}{c}{ TABLE V: MONTE CARLO SIMULATION RESULT } \\
\hline Min (in Million IDR) & $(182.205)$ \\
Max (in Million IDR) & 2.597 .545 \\
Mean (in Million IDR) & 747.929 \\
Standard Deviation (in Million IDR) & 489.905 \\
Prob NPV $<0$ & $6,34 \%$ \\
\hline
\end{tabular}

\section{CONCLUSION}

The conclusion according to financial feasibility study on hydro power plant on West Sumatra are:

1. The investment for hydro power plant on West Sumatra is financially feasible to be executed. It can be seen from the discounted cashflow parameter. The result of the hydro power plant project is positive Net Present Value (NPV) Rp 1.832.776.500.481; Internal Rate of Return (IRR) higher than the Weighted Average of Cost Capital with 15,77\%; Payback Period with 9,15 years and Profitability Index higher than 1 with 5,41.

2. The financial performance from the hydro power plant project on West Sumatra consider to be favorable refer to the profitability index value which is 5,41. In addition, the average profitability ratio shows a favorable result with 
$76,74 \%$ of operating profit margin, $50,52 \%$ of net profit margin, $7,75 \%$ of Return on Assets, and 10,68\% of Return on Equity.

3. According to the sensitivity analysis result, the top five variable that affect the project value when the variable changes its value are long-term debt interest rate, capacity factor, agreement price, inflation rate, and CAPEX need. In addition, the Monte Carlo simulation result shown that there is $6,34 \%$ of probability for the project to become not feasible. To minimize the number, the author proposed some mitigation plan related with the variable which affect the project's value.

\section{RECOMMENDATION}

There are several recommendations for the hydro power plant project on West Sumatra, the recommendation is:

1. Even though the feasibility result shows that the project is feasible, the Monte Carlo simulation result shows that there is $29,11 \%$ of probability the project become not feasible, so the company should control the variable that sensitive to change and minimize the probability of changing the variable number.

The company should consider using partnership scheme or fund the project. As it was mentioned previously that the energy sector seek interest for the private to invest more than the other sector. According to the regulation, the partnership can be done using public private partnership with BOT (Build Operate Transfer) term under the concession period. Under BOT term the company will receive a benefit which made the company did not need to invest money in capital expenditure, because the private partner that will build the power plant and under the concession period, the private partner will operate the power plant and the company will paid for the electricity using the agreement price based on the primary cost in each region that regulated by the government. The company still receive revenue as much as the margin between the selling price and the agreement price. Even though the revenue will not be as much as without the partnership, but the company can have an opportunity to use the money to another potential renewable energy source, so that the target for the renewable energy proportion can be achieved.

The company should ensure that the infrastructure to support the energy source that will be built is supported enough, so that the electricity can be distributed well. If the infrastructure to support the energy source is not supported enough, then the energy produce will be wasted.

\section{REFERENCES}

[1] Awojobi, O., \& Jenkins, G. (2015). Were the hydro dams financed by the World Bank from 1976 to 2005 worthwile? Energy Policy, 222232.

[2] Jovanovic, P. (1999). Application of Sensitivity Analysis in Investment Project Evaluation Under Uncertainty and Risk. International Journal of Project Management, 217-222.

[3] Kementrian PPN / BAPPENAS. (2019). Rencana Pembangunan Jangka Menengah Nasional 2020-2024. Jakarta: Kementrian PPN / BAPPENAS

[4] Otoritas Jasa Keuangan. (2014). Buku Pedoman Energi Bersih. Jakarta: Otoritas Jasa Keuangan.
[5] PT. Kencana Energi Lestari. (2019). Annual Report PT. Kencana Energi Lestari 2019. Jakarta: PT. Kencana Energi Lestari.

[6] Rastogi, N., \& Trivedi, M. (2016). PESTLE Techinque - A Tool to Identify External Risk in Construction Project. International Research Journal of Engineering and Technology, 384-388.

[7] Saltelli, A., Tarantola, S., Campolongo, F., \& Ratto, M. (2004). Sensitivity Analysis in Practice. Chichester: John Wiley \& Sons Ltd.

[8] Thompson, A. A., Gamble, J. E., Peteraf, M. A., \& Strictland III, A. (2015). Crafting and Executing Strategy. New York: Mc-GrawHill.

[9] United Nation. (2017). Global Indicator Framework for The Sustainable Development Goals and Targets of The 2030 Agenda for Sustainable Development. United Nation.

[10] World Bank. (2020, January). Indonesia Data. Retrieved from World Bank: https://data.worldbank.org/country/ID.

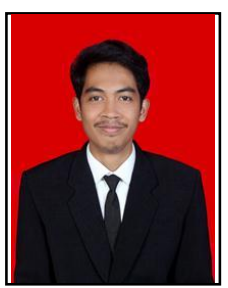

Sidhi Razinda Kautsar was born in Bandung, 25th of December 1994. He earned bachelor's degree in industrial engineering from Institut Teknologi Sepuluh Nopember. He is currently pursuing master's degree in business administration from in Institut Teknologi Bandung and majoring in finance. He has work experience in construction as operation staff for PT Damco Indonesia 2019. Also, as an intern in PT Quadran Rekaya Energi.

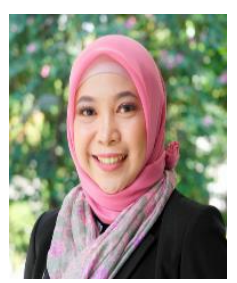

Sylviana Maya Damayanti obtained a Ph.D degree from the Faculty of Economics, Doctorate of Business Management program at the University of Padjadjaran Bandung in 2015. She earned MBA degree from the Institut Teknologi Bandung majoring in Management in 2007 and immediately joined as the lecturer of the interest groups of Business Risks and Finance School of Business and Management, Institut Teknologi Bandung (SBM-ITB). Previously she was dabbling in the world of engineering after graduating from Universitas Islam Sultan Agung, Semarang with a Bachelor's degree in Electrical Engineering in 2002.

Her research interests in the areas of Personal Financial Planning, Financial Management, Investment Management, Financial Literacy \& Inclusion, and Financial Technology. She has produced a variety of publication in the form of scientific papers, popular articles and a book entitled: "Personal Financial Planning - The essence of knowledge in financial planning goals to achieve a prosperous life". Now she is conducting the Financial Literacy and Inclusion Research Center in SBMITB, partnered with The Financial Services Authority (OJK) to raise financial literacy and inclusion in Indonesia. 